\title{
Archaeometallurgy in the Paraná Delta (Argentina): Composition, manufacture, and indigenous routes
}

\author{
Mariano Bonomo ${ }^{\mathrm{a}, *}$, Edgardo D. Cabanillas ${ }^{\mathrm{b}}$, Ricardo Montero ${ }^{\mathrm{c}}$ \\ ${ }^{a}$ CONICET-División Arqueología, Facultad de Ciencias Naturales y Museo, UNLP. Museo de La Plata, Paseo del Bosque s/ $n^{\circ}$, (1900) La Plata, Argentina \\ b CONICET-Comisión Nacional de Energía Atómica, Centro Atómico Constituyentes, Av. Gral. Paz y Constituyentes, San Martín, Argentina \\ ' Comisión Nacional de Energía Atómica, Centro Atómico Constituyentes, Av. Gral. Paz y Constituyentes, San Martín, Argentina
}

\section{A R T I C L E I N F O}

\section{Article history:}

Received 30 May 2016

Revision received 29 December 2016

\section{Keywords:}

Metal circulation

pre-Hispanic times

first Spanish chronicles

La Plata basin

\begin{abstract}
A B S T R A C T
The results of macroscopic, microscopic, and metallographic studies of archaeological metal objects from the Delta of the Paraná River (Argentina, South America) are presented. The aim of these studies was to determine the chemical composition and the manufacturing techniques of these allochthonous objects frequently placed in human burials. The results were discussed taking into account archaeological and ethnohistorical information in order to understand the significance of metals and the indigenous routes to the Paraná River. We concluded that the metal pendants and beads recovered in the Paraná Delta were manufactured from copper by casting in open moulds and hammering. Finished metal objects reached the Paraná River as a result of exchange circuits involving transport across pre-Hispanic routes from the production centres in the Andes. Metal objects from distant geographical areas were used to mark social ranks within the groups and were symbols of prestige displayed by local leaders.
\end{abstract}

(c) 2017 Published by Elsevier Inc.

\section{Introduction}

Metal objects have been one of the most valued goods for human societies all over the world since the emergence of metallurgy. They have been transported for millennia for very long distances, from the sources and metal production workshops to the places of use, as observed in the southern South American Andes (e.g., González, 1992; González et al., 2011). In most parts of the South American lowlands, indigenous people did not make metal objects, but they obtained them through exchange with Andean populations (Steward, 1944-49). The archaeological data (Prümers, 2007; Angiorama and Taboada, 2008) and the sixteenth century ethnohistorical references Combès (2008) and Susnik (1993) show an intense metal circulation from the Meridional Andes Area towards the eastern lowlands. Metal objects from the Calchaquí valleys in the north-west of Argentina have even reached the Patagonia region (more than $1900 \mathrm{~km}$ away in a straight line) as evidenced by a funerary context of the beginning of the Hispanic contact (Gómez Otero, 2003). They circulated as finished objects, ingots or unfinished hammered sheets (thin plates), and were made of copper, bronze alloy and, to a lesser extent, gold and silver.

\footnotetext{
* Corresponding author.

E-mail addresses: mbonomo@fcnym.unlp.edu.ar (M. Bonomo), cabanill@cnea. gov.ar (E.D. Cabanillas), rmontero@cnea.gov.ar (R. Montero).
}

In the case of the La Plata basin, the second biggest basin in the South American lowlands, the first chronicles (e.g., Lopes de Sousa [1531], 1861; Ramírez [1528] in Madero, 1902; Núñez Cabeza de Vaca [1541-1544], 2014) frequently mention metal objects in possession of indigenous people. A few metals have also been recorded in some archaeological sites in the south of this basin, especially in the middle and lower Paraná and Uruguay Rivers (Araújo, 1900; Torres, 1911; Serrano, 1934; Hilbert, 1986; Ceruti, 1993). Based on this and other evidence (the rocks used for knapping, malachite beads, pottery representations of non-native fauna, and possibly the circulation of domestic camelids) it has been proposed (Torres, 1911; Serrano, 1950; Ceruti, 1993; Bonomo et al., 2011; Loponte et al., 2011) that the indigenous populations from the alluvial plains and the delta of the Paraná River were engaged in supraregional social networks which included the circulation and transport of objects from the Meridional Andes Area. This is the main idea that this paper seeks to asses.

The results of macroscopic, microscopic, and metallographic studies of 11 archaeological metal pieces from the Delta of the Lower Paraná River (Argentina) are presented. The objectives of these studies were to determine the chemical composition of the objects and the existence of any sort of alloy, as well as to obtain information about the metallurgical manufacturing techniques. Finally, the results were contextualized by analysing and discussing the supra-regional archaeo-metallurgical data and the ethnohistorical information in order to understand the possible 
origins, routes, and circulation mechanisms of metal objects until they reached the indigenous populations of the Paraná Delta.

\section{Materials and methods}

The studied metal objects are part of the Luis María Torres Collection (División Arqueología of the Museo de La Plata, Universidad Nacional de La Plata). The 11 objects comprise 14 fragments that come from three archaeological sites: Túmulo I del Paraná Guazú (TIPG; located at S $34^{\circ} 1^{\prime}$ and W 58 $41^{\prime}$ ), Túmulo II del Paraná

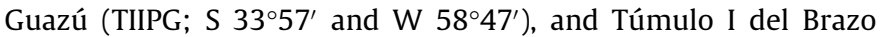

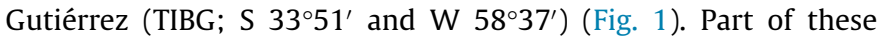
pieces and their discovery context were partially described by Torres (1911). He presents the results of his fieldwork on these three earth mounds where, besides the pieces analysed here, he also recovered abundant smoothed and incised pottery, bone tools, lithic artefacts, endocarps of palm fruits, and faunal remains of fish, deer, felines, and freshwater molluscs, along with numerous human skeletons (for a review of Torres Collection see Bonomo et al., 2009). Three radiocarbon dates were obtained on these sites: $576 \pm 42{ }^{14} \mathrm{C}$ years BP for TIPG (AA-93215; Bonomo et al., 2011: 312), $846 \pm 41{ }^{14} \mathrm{C}$ years BP for TIIPG (AA-72633; Bernal, 2008: 94) and $752 \pm 41{ }^{14} \mathrm{C}$ years BP for TIBG (AA-72635; Bernal, 2008: 94).

Torres (1911: 578) published wet-chemical analysis of four pieces $^{1}$ from TIIPG, performed by Herrero Ducloux, the first doctor in chemistry in Argentina, who identified a marked predominance of copper $(\mathrm{Cu})$. Besides this precedent, there are few analyses of the chemical composition of metal artefacts in the region. They are only limited to indigenous settlements from the initial period of the Hispanic contact (Las Conchas site, Serrano, 1934 and possibly Arroyo Fredes site, Loponte et al., 2011) and settlements of European origin, which are not included in this paper, such as Santa Fe la Vieja city founded in 1573 (e.g. Fester and Retamar, 1955) and the Franciscan missions of Santiago del Baradero founded in 1615 (Debenedetti, 1910; Tapia et al., 2009). Most of these studies recorded brass objects (a Cu-Zn alloy) unknown in pre-Colombian America.

In the present study the following analyses were performed:

(1) Macroscopic analysis: All metal pieces were weighed with an Ariete Libra 850 electronic scale ( $1.0 \mathrm{~g}$ accuracy), measured with a vernier caliper $(0.1 \mathrm{~cm}$ accuracy), and morphologically described (Table 1 ).

(2) Chemical composition and corrosion: Several measurements by Energy Dispersive X-ray Spectrometry (EDS) were made on the surface of micro areas with and without patina of each of the 11 pieces. Based on these results and other features, such as colour and texture, the oxides and carbonates adhered to the surface of the pieces were also identified. The EDS analyses were done with EDAX equipment coupled to a FEI Quanta 200 scanning electron microscope (SEM-EDS).

(3) Manufacturing work: In order to evaluate microstructurally the morphological characteristics and the manufacturing methods, all of the 11 pieces and the metallographic replicas made from three of them (one from each archaeological site) were observed with SEM at different magnifications. The replica technique was used because of its minor alteration procedure in order to preserve the museum collection pieces. The three samples were selected after the EDS analysis of all the pieces, searching for the representation of the different chemical compositions, of the distinct types of objects, and of the three archaeological sites with separate

\footnotetext{
1 Two of these pieces ( $N^{\circ} 2$ and 4; see Fig. 86 in Torres, 1911: 258) could not be
} located in the collection stored at the División Arqueología of Museo de La Plata. chronologies. The area studied was prepared according to the specifications of the ASTM E-3 and the ASTM E-1351 standards (i.e., standards for the preparation of a metallographic specimen and replica, respectively); the development of the microstructure was performed according to the ASTM E-407 standard (i.e., standard procedures for the development of the microstructure). The metallographic microscope used in these studies was an Olympus BMX 51.

\section{Results}

\subsection{Macroscopic analyses}

The metallic pieces are part of ornaments, possibly pendants and beads, and they all have holes to be suspended (Table 1). They have semi-lunar, trapezoidal, rectangular, and quadrangular shapes with rounded corners. They are light, small, and very thin: weight $<15 \mathrm{~g}$, length $<20 \mathrm{~cm}$, and very uniform thickness $\leq 0.1 \mathrm{~cm}$. The rectangular (TIIPG $\mathrm{N}^{\circ} 4$ ) and quadrangular (TIBG $\mathrm{N}^{\circ} 11$ ) pendants were embossed with a blunted point, making a bass-relief decoration formed by a succession of points of $c a$. $2 \mathrm{~mm}$ in diameter around the perimeter of the pieces. In four of the pieces (TIIPG $\mathrm{N}^{\circ} 4$, TIBG $\mathrm{N}^{\circ} 6, \mathrm{~N}^{\circ} 7$ and $\mathrm{N}^{\circ} 11$ ), it can be observed that the suspension hole was made through mechanical action with a pointed element perforating from one of the piece surfaces and leaving an irregular burr of metal material around the hole on the opposing surface.

\subsection{Chemical composition and corrosion}

The metal used for manufacturing all the pieces is mainly pure $\mathrm{Cu}$, as indicated by EDS analyses (Fig. 2a and b). Analyses of the particles as well as the matrix of the surfaces without patina show only $\mathrm{Cu}$ and no detectable alloy compounds. The composition of the semi-lunar pendant is an exception in the entire object assemblage (Fig. 2c). In this particular piece, in addition to a $\mathrm{Cu}$ predominance, tin (Sn) was found as another main element, which represents a percentage in weight up to $9.6 \%$. For this reason, it is classified as bronze formed by a $\mathrm{Cu}-\mathrm{Sn}$ alloy. The intentional incorporation of $\mathrm{Sn}$ improves the mechanical properties and decreases the copper's reddish colour, making the pieces look more golden (González, 2002; Palacios, 2011).

In addition, traces of $\mathrm{Fe}, \mathrm{O}, \mathrm{P}, \mathrm{Cl}, \mathrm{C}, \mathrm{S}, \mathrm{Si}, \mathrm{Al}$, and $\mathrm{Ca}$ were detected. These contaminant elements were found mainly on the unpolished zones and they come from the Cu oxide and other elements that are present on the superficial patinas ( $\mathrm{Fe}, \mathrm{O}, \mathrm{Cl}, \mathrm{Si}, \mathrm{Ca}, \mathrm{S}$ ), from the contact with the sedimentary matrix where the objects were deposited (Si, Al, Ca, P, Cl) (Fig. 2d) (see Angiorama, 2001), and possibly from the decomposition of adjacent human burial ( $P$ and C). Precisely, in metal pieces from funerary contexts, such as the ones studied here, the corrosive processes are intensified due to the combination of environmental conditions and alterations generated by the organic substances during the decomposition of the bodies (Pifferetti, 2001:787).

The analysed pieces show stratified corrosion layers formed by different combinations of $\mathrm{Cu}$ minerals. On their external surfaces, a patina has been formed by quite stable $\mathrm{Cu}$ carbonates that naturally protect the metal. However, besides this stable dark green patina, in some cases the carbonates have been combined with other products of corrosion that are highly active and have an adverse effect on the preservation of the material structure. These compounds are the $\mathrm{Cu}$ chlorides in a light green colour and a powdery texture. Beneath these layers made by salts, continuous reddish surfaces have been generated, which constitute passivation patinas formed by the oxidation of $\mathrm{Cu}$. They isolate the metal, thus favouring its preservation. The original metallic core can be 


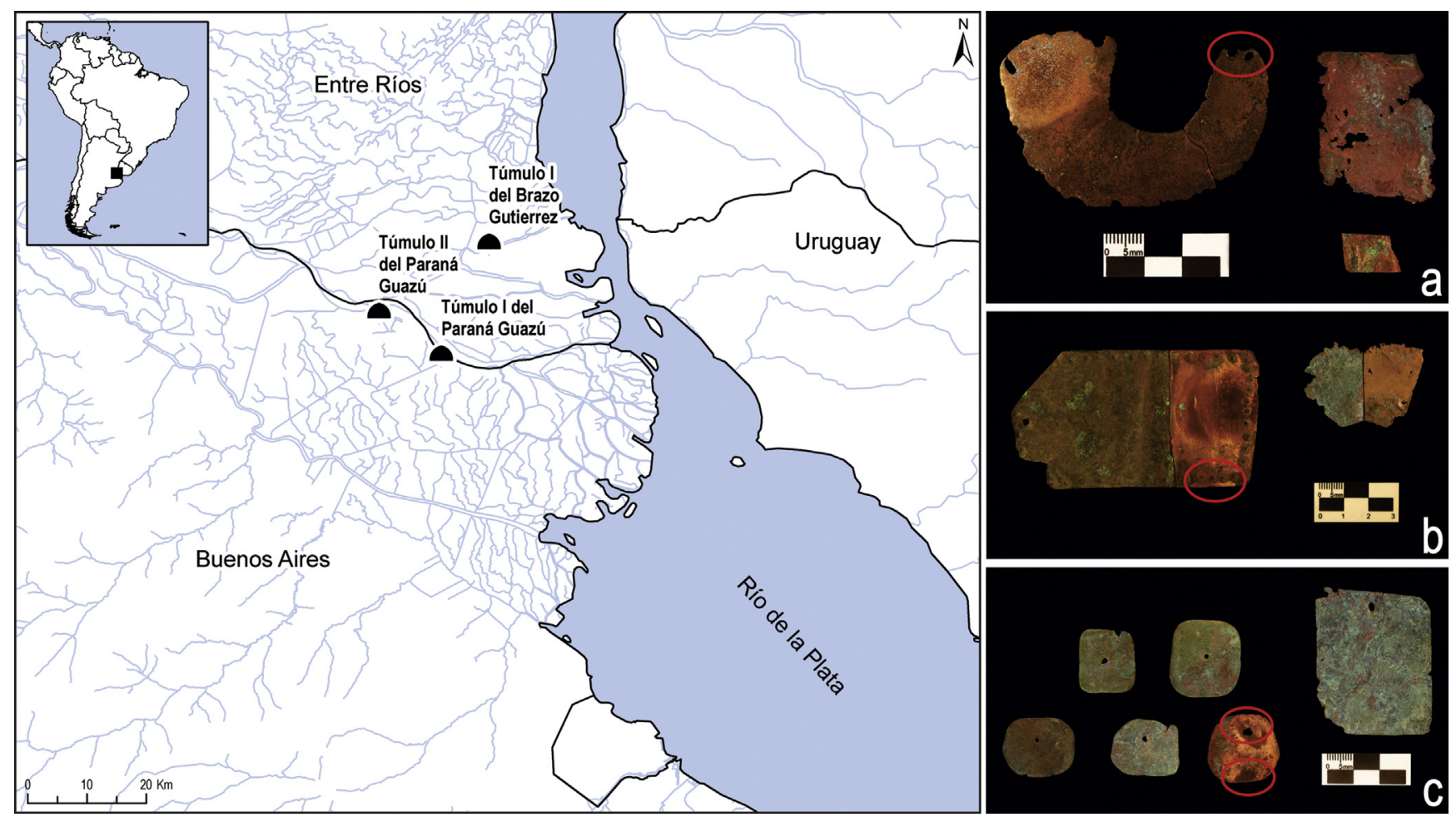

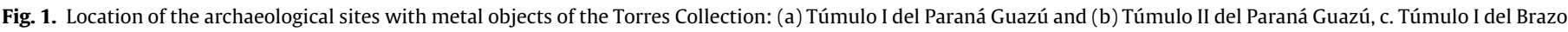
Gutiérrez.

Table 1

Weight, dimensions, morphology and possible function of the metal pieces from the sites Túmulo I and Túmulo II del Paraná Guazú and Túmulo I del Brazo Gutiérrez.

\begin{tabular}{|c|c|c|c|c|c|c|c|}
\hline Piece & $\begin{array}{l}\mathrm{N} \text { of } \\
\text { frag-ments }\end{array}$ & Possible function & Morphology & $\begin{array}{l}\text { Weight } \\
\text { (g) }\end{array}$ & $\begin{array}{l}\text { Length } \\
(\mathrm{cm})\end{array}$ & $\begin{array}{l}\text { Width } \\
(\mathrm{cm})\end{array}$ & $\begin{array}{l}\text { Thickness } \\
(\mathrm{cm})\end{array}$ \\
\hline$\underline{\mathrm{TIPG}^{\circ}}{ }^{\circ} 1$ & 2 & Pendant & Semi-lunar with two suspension holes in both rounded ends & 13 & 7.1 & 3.1 & 0.1 \\
\hline$\overline{\mathrm{TIPG}} \mathrm{N}^{\circ} 2$ & 1 & Indet. & Rectangular fragment & 2 & 3.9 & 3.2 & $<0.1$ \\
\hline TIPG N`3 & 1 & Indet. & Rectangular fragment & 0.5 & 1.4 & 1 & $<0.1$ \\
\hline TIIPG N${ }^{\circ} \underline{a}^{\mathrm{a}}$ & 2 & Pendant & Rectangular with a perforation on a side ${ }^{c}$ & 17 & 10 & 5.7 & $<0.1$ \\
\hline TIIPG N ${ }^{\circ}$ & 2 & Indet. & Irregular fragments & 4 & 5.4 & 3.6 & $<0.1$ \\
\hline TIBG $N^{\circ} 6$ & 1 & Bead & Quadrangular with rounded corners and a central perforation & 2 & 2.4 & 2.2 & $<0.1$ \\
\hline TIBG $N^{\circ} 7$ & 1 & Bead & Quadrangular with rounded corners and a central perforation & 3 & 3.1 & 2.8 & $<0.1$ \\
\hline TIBG N ${ }^{\circ} 8$ & 1 & Bead & Quadrangular with rounded corners and a lateral centre perforation & 3 & 2.8 & 2.3 & $<0.1$ \\
\hline TIBG $N^{\circ} 9$ & 1 & Bead & Quadrangular with rounded corners and edges and a perforation & 2 & 2.6 & 2.1 & 0.1 \\
\hline$\underline{\text { TIBG } N^{\circ}} \underline{10}$ & 1 & Bead & Trapezoidal with rounded corners and edges and a lateral centre perforation & 3 & 2.8 & 2.6 & $<0.1$ \\
\hline$\overline{\text { TIBG } N^{\circ}} \overline{11}$ & 1 & Pendant & Rectangular with a perforation on a side & 7 & 5.9 & 4.8 & $<0.1$ \\
\hline
\end{tabular}

Note: The metallographic analyses were performed on the three underlined pieces.

a Corresponding to piece $\mathrm{N}^{\circ} 1$ in Torres (1911: Apendix IV).

b Could be a fragment of piece $\mathrm{N}^{\circ} 3$ in Torres (1911: Apendix IV).

c There is a missing fragment of this piece due to a modern cut, possibly product of Torres analysis (1911: see Figure 86).

observed underneath this first corrosion layer, especially on the fractures.

\subsection{Metallographic and scanning electron microscope analyses}

Piece of tin bronze: The two suspension holes on one of the ends of this semi-lunar pendant (TIPG $\mathrm{N}^{\circ} 1$ ) were studied: a complete hole $(0.3 \times 0.5 \mathrm{~cm})$ and an incomplete hole (Fig. 1a). The observed primary micro-structure is typical of a piece made by casting. The metallographic analyses of both holes edges show no plastic deformation. Even though the edge of the complete suspension hole (Fig. 3a) is very irregular due to corrosion, it does not present any evidence of mechanical work by pounding and it preserves the signs of the primary manufacture process, that is, the casting. This is evidenced by its dendritic structure (Fig. 3b) and the sub-grains with precipitates (Fig. 3c) and without twins. The edge of the incomplete suspension hole presents a solidification structure (Fig. 3d) similar to that of the other hole. The morphology (Fig. 4a) and the absence of plastic deformation on the edges of the suspension holes indicate that they were also made during the alloy melting. Therefore, the manufacture hypothesis is that this piece was made by casting in an open mould or bivalve whose interior had the shape of the pendant and contained some sort of implement with an oval section that could craft the holes. In addition, it is interesting to note the morphology of the precipitates or $\mathrm{Cu}$ oxides formed and their alignment in the dendritic zone (Fig. 4b), as they show heterogeneities in the casting process.

Cu pieces: The trimmed area of the rectangular pendant (TII PG $\left.\mathrm{N}^{\circ} 4\right)$ was analysed in detail, as well as two beads with patinas (TIBG $\mathrm{N}^{\circ} 6$ and 9; Fig. 5a), and one bead without it (TIBG $\mathrm{N}^{\circ} 10$ ). 

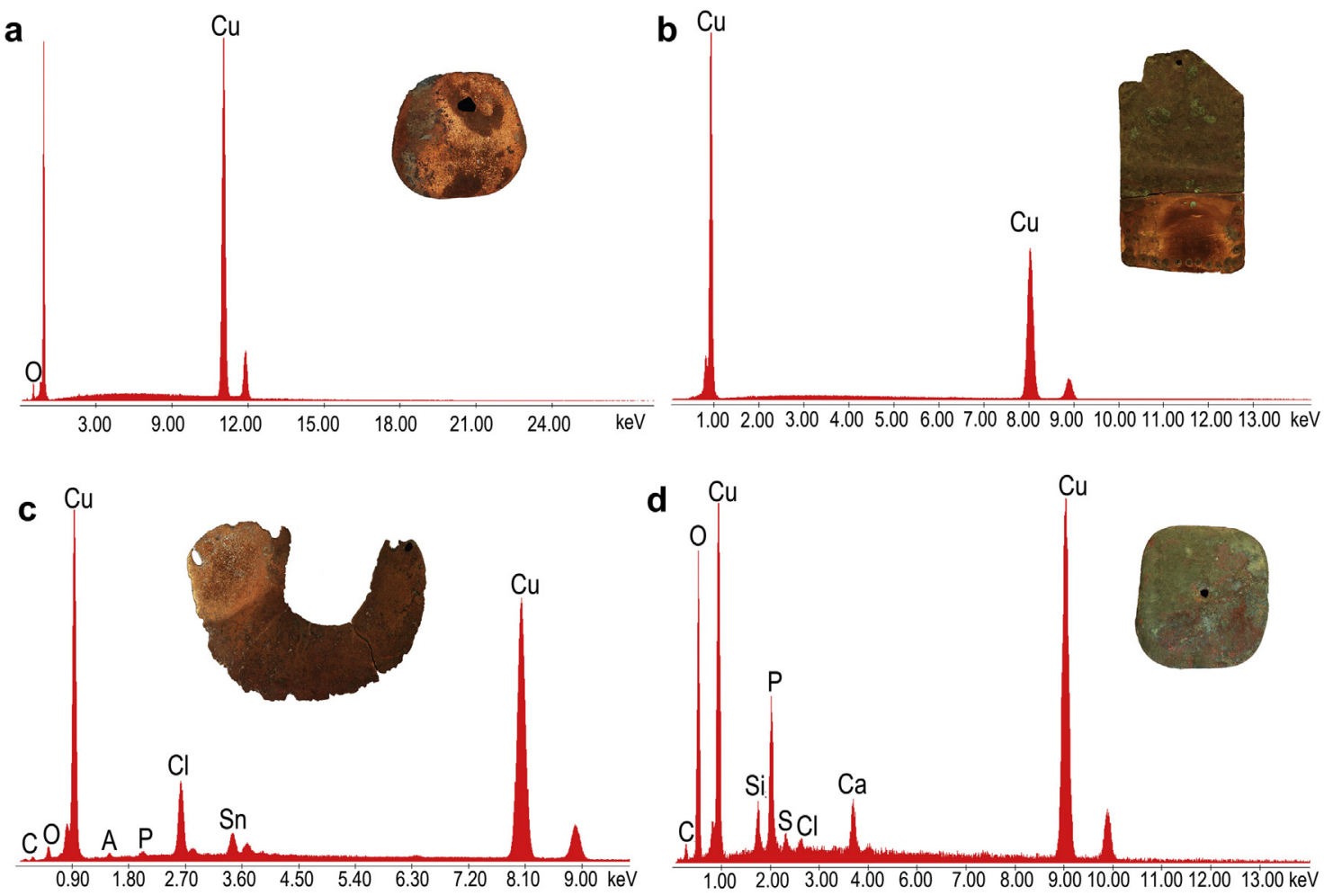

Fig. 2. Energy dispersive X-ray micro-analysis. (a) Particle of TIBG $\mathrm{N}^{\circ} 10$, (b) Matrix of TIIPG $\mathrm{N}^{\circ} 4$, (c) Piece TIPG $\mathrm{N}^{\circ} 1$, and (d) Superficial patina of TIBG $\mathrm{N}^{\circ} 6$.
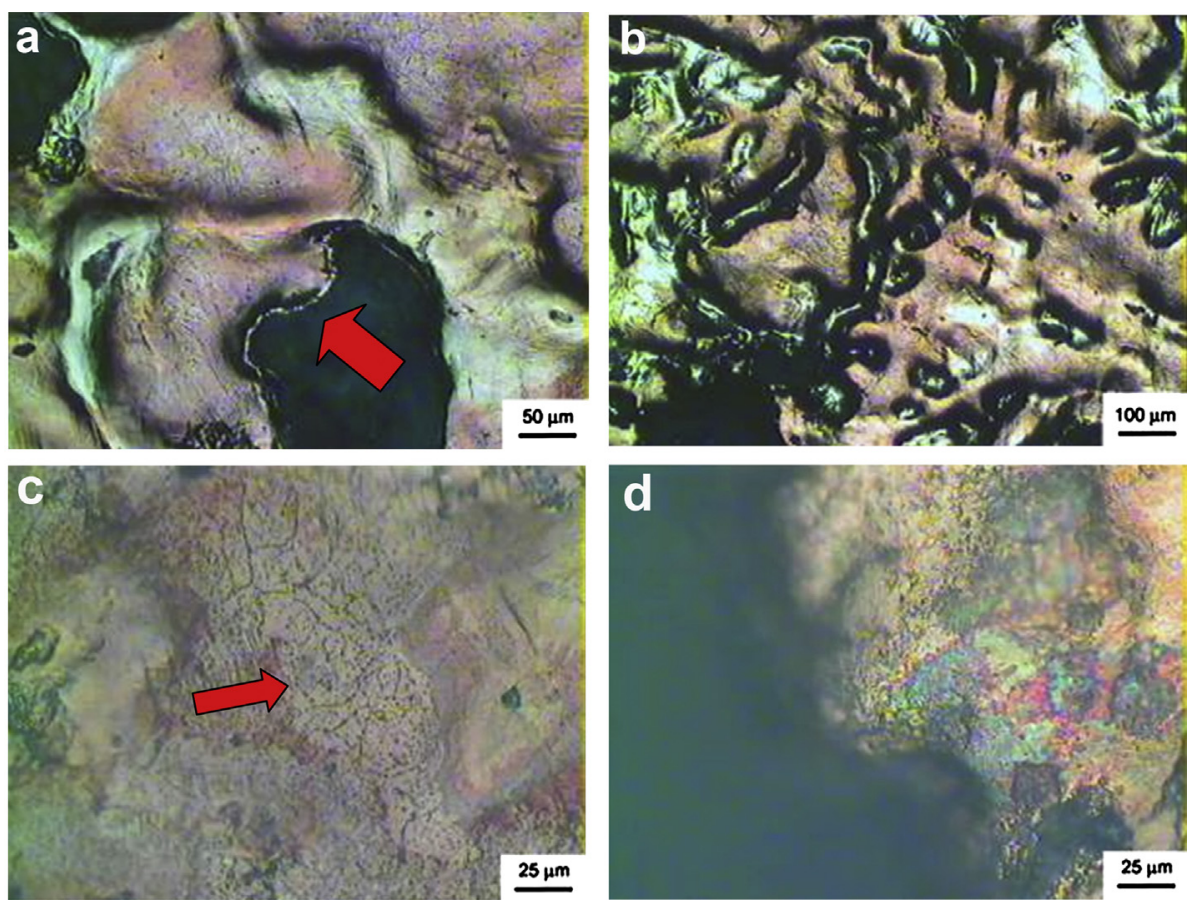

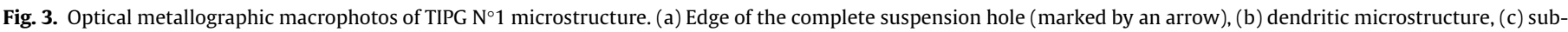
grains with precipitates (marked by an arrow), and (d) primary solidification microstructure of the edge of the incomplete suspension hole.

The perforated zones and perimeter edges of these pieces were microscopically observed. The metallographic study of the rectangular pendant yielded the same manufacture process than in TIBG $\mathrm{N}^{\circ} 10$; therefore, we will focus on the description of this latest piece. The metallographies indicate that the initial manufacture stage involved alloy melting in the form of a small ingot or a bigger chunk of pure $\mathrm{Cu}$. Precisely, the micro-shrinkage cavities observed in Fig. 6a are defects generated during ingot melting. The observed oxides precipitation (Figs. 5b, Fig. 6b) shows poor deoxidation of the liquid metal during melting. There are no traces of mechanical work or cutting (shearing) on the perimeter edge; instead, it also has defectology on the melting. 

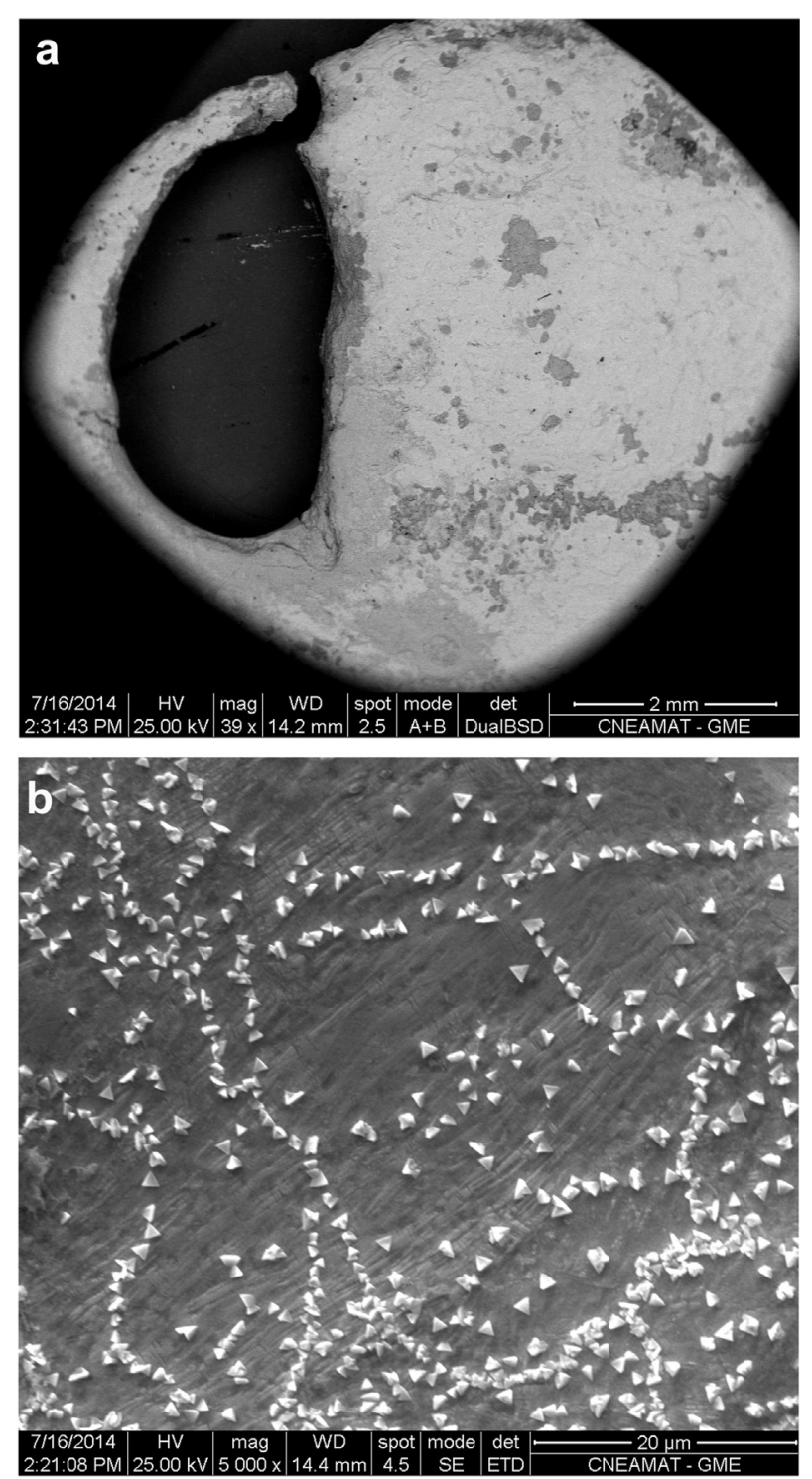

Fig. 4. Scanning electron microscope micrographies of TIPG $\mathrm{N}^{\circ} 1$. (a) Suspension hole morphology and (b) precipitates of the interdendritic spaces.

Annealing twins were observed in the matrix (Fig. 6c). They were generated when the piece was reheated due a thermomechanical treatment during forming and when recrystallization processes occurred. The twins indicate that the thickness of the piece was obtained by lamination or hammering (Fig. 5c). This type of mechanical deformation that increases the sheet hardness can be discerned by the oxides orientations (Fig. 6b), which follow the hammering direction. In Fig. $6 c$ and $d$ the matrix with annealing twins was observed over a previous inter-dendritic phase, which is characteristic of molten material prior to this hot forming. Therefore, the middle manufacture stage included hammering to stretch the sheets and annealing at temperatures below melting.

Finally, SEM micrographies make it possible to analyse some details in TIBG $\mathrm{N}^{\circ} 6$ and TIIPG $\mathrm{N}^{\circ} 4$. Bead TIBG $\mathrm{N}^{\circ} 6$ has a deformed crater-shaped edge (Fig. 5d), which was probably perforated in cold. This plastic deformation around the hole indicates that it was made through manual mechanical action with a pointed object. In the case of the trim on pendant TIIPG $N^{\circ} 4$, the holes' morphology and microstructure (Fig. 5e and f) indicate that they were made on a mould during casting. In these holes there are annealing twins, oriented precipitates, and a heterogeneous distribution of the production phases, which indicate that areas with different proportions of alloying have been generated during casting.

\section{Discussion}

The metal objects found in the Paraná Delta are the final product of specialized technology. The production sequence included the selection and extraction of $\mathrm{Cu}$ and $\mathrm{Sn}$ from different mineral deposits, grinding of metalliferous ores, smelting in special ovens usually at temperatures above $1000{ }^{\circ} \mathrm{C}$, casting liquid metal in open moulds, and different manufacturing and decoration techniques: hammering, drilling, deburring, polishing and embossing (González, 1992; Palacios, 2011). There are no Cu or Sn sources in the Delta; thus, the extraction would not have been done in the studied area. In addition, no remains of raw metalliferous minerals have been found, nor is there any evidence of the manufacture of metal objects (e.g., ovens, ceramic tubes, stone or ceramic moulds, containers with metal adhesions that may be assigned to crucibles, tools such as chisels or hammers, remains of melted mineral in the form of slag) like those recorded in regions such as the north-west of Argentina (NWA), where there is a clear development of the metallurgic technology during pre-Hispanic times (Amborsetti, 1904; Pifferetti, 2002; Palacios, 2011; Campos, 2009). For this reason, it is proposed that metallurgy in the Lower Paraná River is a foreign technology and that the metal objects reached the area as finished products.

The first metal records in the Lower and Middle Paraná River (Table 2) date back to 967-1154 cal years AD and 1175-1283 cal years $A D$, respectively. They are prior to the arrival of the Incas in NWA (early fifteenth century), and they overlap the late period known as Desarrollos Regionales in NWA (ninth to fifteenth centuries), where $\mathrm{Cu}$ and tin bronze metallurgy had a great development (González and Gluzman, 2007:193, 195, 196). The nearest NWA archaeological sites of the Desarrollos Regionales and Inca periods are located at distances greater than $900-1000 \mathrm{~km}$ in a straight line of the studied sites of the Paraná Delta. This distance is actually greater if we take into account the mountainous reliefs of the region. The cultural developments in the NWA did not have a direct impact on the Paraná Delta, although they possibly did affect a greater circulation of goods to remote areas. The arrival of the Incas in the NWA induced an increase in both the metallurgical production and the circulation flow of finished products (González and Gluzman, 2007).

As shown in Table 2, few Cu disks, beads and sheet fragments have been recovered in some archaeological sites in the Lower and Middle Paraná and Uruguay Rivers, and the Northern Pampas region. Most of these materials are ornaments that were frequently included in burial contexts as the funerary objects of some individuals. The practice of placing metal pieces along with the body of certain individuals, usually next to the head, was initially seen in pre-Hispanic archaeological sites. It has also been recorded in sites with late radiocarbon dates and imported objects that belong to post-Hispanic times, when metal pieces were buried along with glass beads of European origin. Metals were recovered in sites from the studied area associated with different archaeological entities, such as Goya-Malabrigo and Guaraní, showing that these objects circulated among different indigenous populations of the region, even after the arrival of the Spanish and Portuguese. Therefore, the first European observations of the local indigenous people can be very useful for understanding how the metals came to the Paraná River.

Since the beginning of the European conquest in the sixteenth century, several references to the Paraná River and neighbouring areas have been made about individuals from different indigenous populations having metal objects: Chaná-timbú, Guaraní, Quer- 

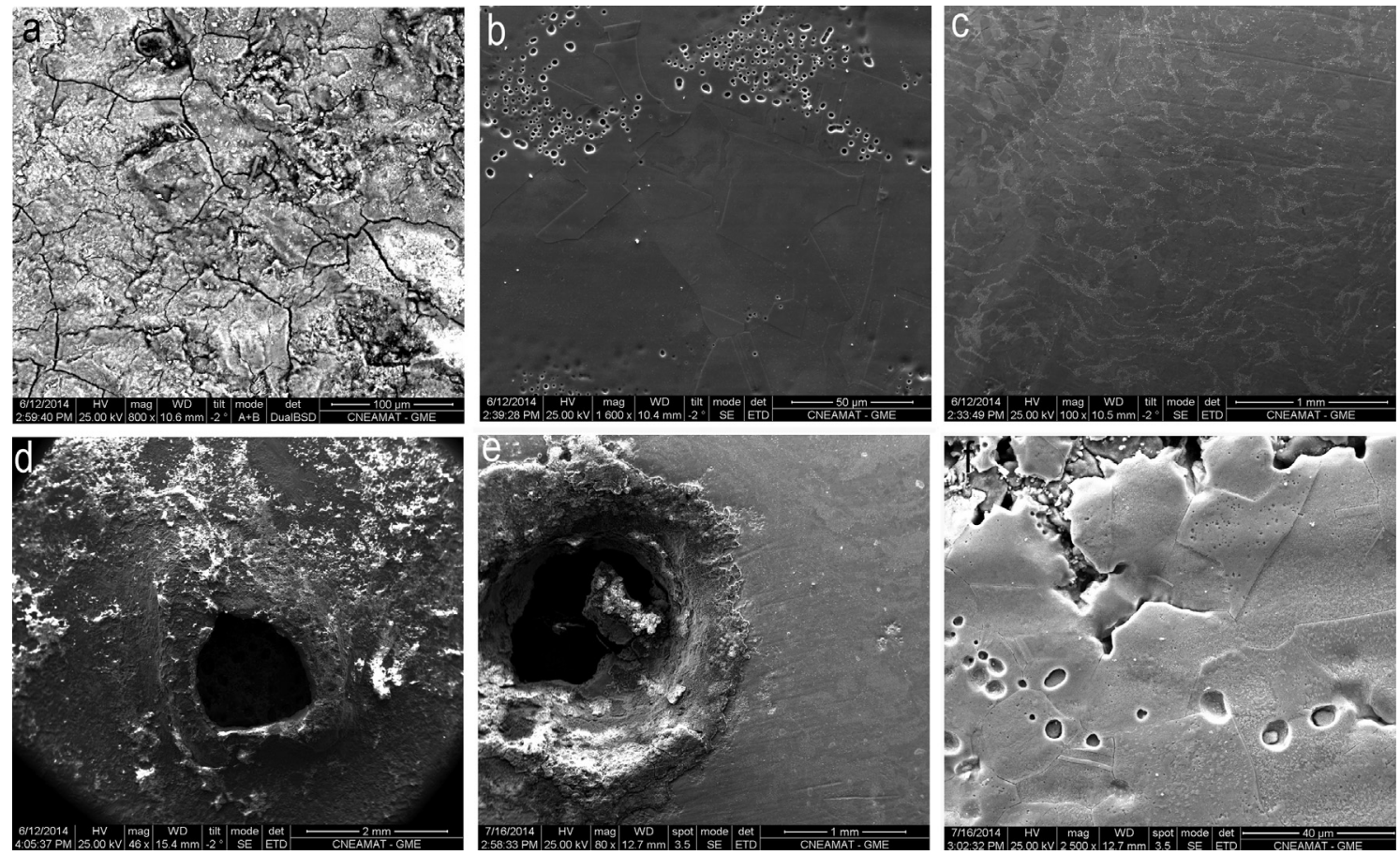

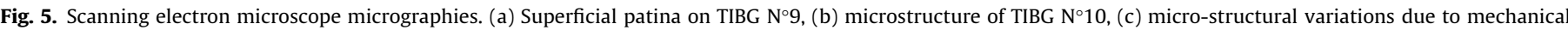

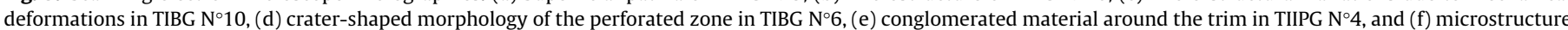
with small twins and corroded material around the trim in TIIPG $\mathrm{N}^{\circ} 4$.
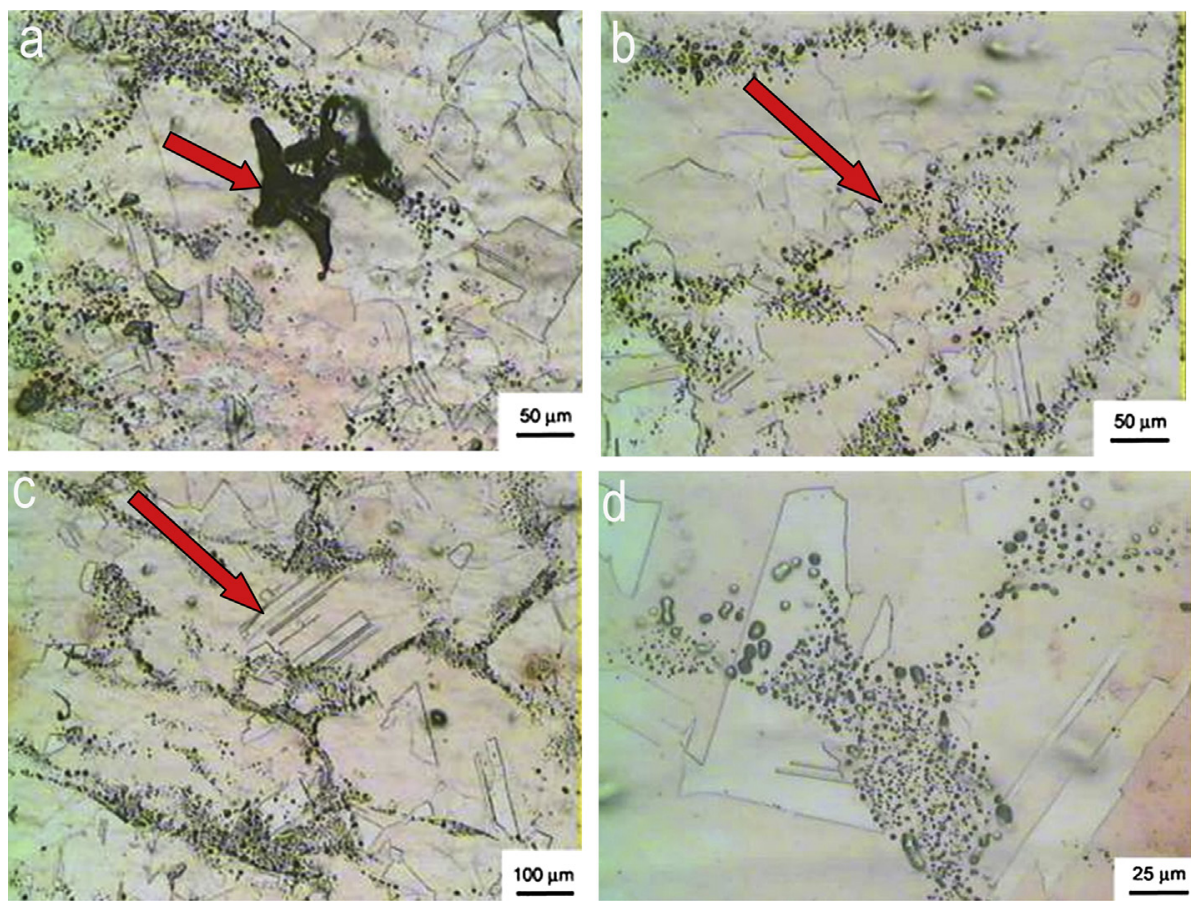

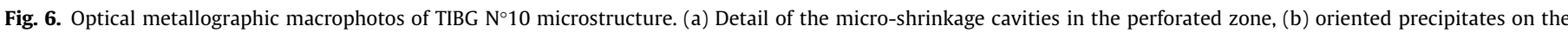
perimeter edge, (c) matrix where the arrow marks annealing twin on the perimeter edge, and (d) morphology of the phases in the perimeter edge.

andíes, and different indigenous Chaco groups (Fig. 7). The Chanátimbú (including Timbú and Carcaraes people) were canoe groups that lived mainly in the alluvial plain and islands of the Middle and Lower Paraná River, systematically exploited the fluvial resources, and cultivated maize, squash and beans. The Guaraní also inhabited the same river, but north and south of the Chaná-timbú, and they practiced more intensive horticulture. The Querandies and some Chaco groups were mobile foragers who approached the shores of the Paraná to fish and to exchange goods with the riverine populations. Utilitarian objects and especially various ornaments circulated among the populations of the vast region known at that time as in Río de la Plata. The first sixteenth century 
Table 2

Archaeological sites with metallic objects from Paraná and Uruguay rivers (Middle and Lower sections) and the Northern Pampas region

\begin{tabular}{|c|c|c|c|c|c|}
\hline $\begin{array}{l}\text { Archaeological } \\
\text { site }\end{array}$ & $\begin{array}{l}\text { General } \\
\text { location }\end{array}$ & $\begin{array}{l}\text { Pieces/raw } \\
\text { material }\end{array}$ & Context & $\begin{array}{l}\text { Chronology }{ }^{14} \mathrm{C} \text { years } \\
\text { BP (cal years AD) }\end{array}$ & References \\
\hline Querandí & $\begin{array}{l}\text { Northern } \\
\text { Pampa }\end{array}$ & Necklace bead/Cu & Along with ceramics and lithics & - & Villegas Basavilbaso (1937) \\
\hline Arroyo Malo & $\begin{array}{l}\text { Lower } \\
\text { Paraná }\end{array}$ & $\begin{array}{l}\text { Scabbard tip/Cu } \\
\text { alloy }\end{array}$ & $\begin{array}{l}\text { Along with indigenous ceramics, } \\
\text { glass and green glaze pottery } \\
\text { (Guaraní) }\end{array}$ & $442 \pm 45(1428-1626)$ & $\begin{array}{l}\text { Lothrop (1932) and Bonomo et al. (2015); } \\
\text { División Arqueología Collection of Museo de La } \\
\text { Plata }\end{array}$ \\
\hline Arroyo Fredes & $\begin{array}{l}\text { Lower } \\
\text { Paraná }\end{array}$ & $\begin{array}{l}2 \text { metal disks, } 1 \\
\text { artefact/bronze }\end{array}$ & $\begin{array}{l}\text { Along with ceramics, lithics and } \\
\text { fauna }\end{array}$ & $402 \pm 40(1453-1627)$ & Loponte et al. (2011) \\
\hline $\begin{array}{l}\text { Túmulo I del } \\
\text { Paraná } \\
\text { Guazú }\end{array}$ & $\begin{array}{l}\text { Lower } \\
\text { Paraná }\end{array}$ & $\begin{array}{l}1 \text { ornament/ } \\
\text { bronze, } 2 \\
\text { fragments/Cu }\end{array}$ & ( & $576 \pm 42(1385-1448)$ & Torres (1911), Bonomo et al. (2011) \\
\hline $\begin{array}{l}\text { Túmulo II del } \\
\text { Paraná } \\
\text { Guazú }\end{array}$ & $\begin{array}{l}\text { Lower } \\
\text { Paraná }\end{array}$ & $\begin{array}{l}1 \text { ornament } / \mathrm{Cu}, 2 \\
\text { fragments } / \mathrm{Cu}\end{array}$ & Funerary & $846 \pm 41(1175-1283)$ & $\begin{array}{l}\text { Torres (1911), Bonomo et al. (2009), Bernal } \\
\text { (2008) }\end{array}$ \\
\hline $\begin{array}{l}\text { Túmulo I del } \\
\text { Brazo } \\
\text { Gutiérrez }\end{array}$ & $\begin{array}{l}\text { Lower } \\
\text { Paraná }\end{array}$ & $\begin{array}{l}5 \text { beads } / \mathrm{Cu}, 1 \\
\text { fragment } / \mathrm{Cu}\end{array}$ & Funerary & $752 \pm 41(1226-1321)$ & $\begin{array}{l}\text { Torres (1911), Bonomo et al. (2009), Bernal } \\
\text { (2008) }\end{array}$ \\
\hline $\begin{array}{l}\text { Túmulo II del } \\
\text { Brazo Largo }\end{array}$ & $\begin{array}{l}\text { Lower } \\
\text { Paraná }\end{array}$ & Green stain & Funerary & $756 \pm 46(1222-1323)$ & $\begin{array}{l}\text { Bonomo et al. (2009), Mazza (2015), Politis et al. } \\
\text { (2015) }\end{array}$ \\
\hline Paranacito & $\begin{array}{l}\text { Lower } \\
\text { Paraná }\end{array}$ & $\begin{array}{l}\text { Disk with a } \\
\text { suspension hole/ } \\
\mathrm{Cu}\end{array}$ & Funerary & - & 1938 S. Gatto Collection, Museo Etnográfico, UBA \\
\hline Punta Chaparro & $\begin{array}{l}\text { Lower } \\
\text { Uruguay }\end{array}$ & $\begin{array}{l}2 \text { rectangular } \\
\text { sheets } / \mathrm{Cu}\end{array}$ & Funerary & - & Hilbert (1986) \\
\hline Los Cardos & $\begin{array}{l}\text { Lower } \\
\text { Uruguay }\end{array}$ & $\begin{array}{l}2 \text { quadrangular } \\
\text { sheets? }\end{array}$ & - & - & $\begin{array}{l}\text { A. Toscano Collection, Museo Nacional de } \\
\text { Antropología de Montevideo; Gascué pers. comm. } \\
2015\end{array}$ \\
\hline Isla del Vizcaíno & $\begin{array}{l}\text { Lower } \\
\text { Uruguay }\end{array}$ & 3 disks $/ \mathrm{Cu}$ & Funerary (Guaraní) & Post-Hispanic & Araújo (1900), Hilbert (1986) \\
\hline La Palmera II & $\begin{array}{l}\text { Middle } \\
\text { Paraná }\end{array}$ & $\begin{array}{l}\text { Rectangular } \\
\text { perforated plate/ } \\
\mathrm{Cu}\end{array}$ & Funerary (Goya-Malabrigo) & $\begin{array}{l}1056 \pm 47(967-1154) \\
1032 \pm 47(985-1162)\end{array}$ & Ceruti (1993), Ottalagano et al. (2015) \\
\hline Las Conchas & $\begin{array}{l}\text { Middle } \\
\text { Paraná }\end{array}$ & 3 fragments/brass & Funerary (Goya-Malabrigo) & Post-Hispanic & Serrano (1934) \\
\hline Y 57 & $\begin{array}{l}\text { Middle } \\
\text { Uruguay }\end{array}$ & Pieces/Cu & Funerary & - & MEC (1989) \\
\hline Y 58 & $\begin{array}{l}\text { Middle } \\
\text { Uruguay }\end{array}$ & Pieces/Cu & - & Post-Hispanic & MEC (1989) \\
\hline
\end{tabular}

a Calib 7.0.2 program, using 2 sigma and SHCal13.

chronicles (Fernández de Oviedo y Valdés [1546-47], 1852:194; Lopes de Sousa [1531], 1861:62; Ramírez [1528] in Madero, 1902:400, 404; Núñez Cabeza de Vaca [1541-1544], 2014:177) mention that the indigenous people possessed copper, silver and gold nose-rings, ear-ornaments, lip plugs (named tembetás), bracelets, headdresses, tiaras or crowns, pins, containers, axes, and metal sheets or plates. The La Plata River might even have taken its name from a silver axe obtained by the Portuguese expedition of D. Nuno Manuel and Cristóvão de Haro in 1514 (Keating and Maranhão, 2011:110).

In the particular case of the Lower Paraná, the first chronicles mention that gold, silver, and other metal objects were in possession of some individuals and had an allochthonous origin, "they brought them from other places" 2 (Fernández de Oviedo y Valdés [1546-47], 1852:178). A question quickly arises: where did they bring them from? In order to answer this, it is necessary to assess what the archaeological and ethnohistorical evidence shows about metals in neighbouring areas of the Paraná River. The river and land trajectories used by indigenous people to guide the first European expeditions in the sixteenth century allow us to elucidate three potential routes: (1) from the Carcarañá River to the Mountain Ranges of Córdoba Province, (2) along the Salado-Dulce rivers through Santiago del Estero Province, and (3) along the ParanáParaguay rivers and across Chaco region. Routes 1 and 2 were shown by indigenous people of the Paraná River to Caboto (1526-30) during

\footnotetext{
${ }^{2}$ All chronicle translations are simplified interpretations from sixteenth century Spanish.
}

the first expedition that went deep into this river and described different local populations that had not been previously contacted by Europeans (Areces et al., 1989-90).

We now focus on the information gathered from the nearby areas and regarding these three potential circulation routes: (1) In the archaeological record of the neighbouring Province of Córdoba (Serrano, 1945), breastplates have been found along with human burials, sheets, and other Cu objects, some of which could correspond to post-Hispanic times. The ethnohistorical record also contains several references to the use of metals by indigenous people. Regarding the Mountain Ranges of Córdoba and in particular the local groups called Comechingones, the classical 1573 Anonymous Account tells: "Most of them wear headdresses made of wool and many long metal rods with spoon-shaped tail ends" (Serrano, 1945:100). It is also mentioned that the Comechingones and the Sanavirones (the latter are other indigenous people from Córdoba Province) "they bring feathers of copper and other metals, bracelets and medallions, copper and other metals" (Sotelo de Narváez 1583 in Berberián, 1987:242). According to Serrano (1945) and based on historical documents, these objects were not manufactured in Córdoba. They were instead obtained by exchange, and one of the main areas of origin was possibly La Rioja Province through the Diaguitas indigenous people, who lived there. Precisely, the closest sources of $\mathrm{Cu}$ and $\mathrm{Sn}$ to the Paraná Delta sites analysed here are located in La Rioja Province (Fig. 7), over $700 \mathrm{~km}$ (Sierra de Ulapes, Sierra de Chepes and Sierra de las Minas) and $900 \mathrm{~km}$ (Sierra de Velasco and Mazán) away in a straight line, respectively (Angelelli, 1984; Godeas et al., 1999). While there are 


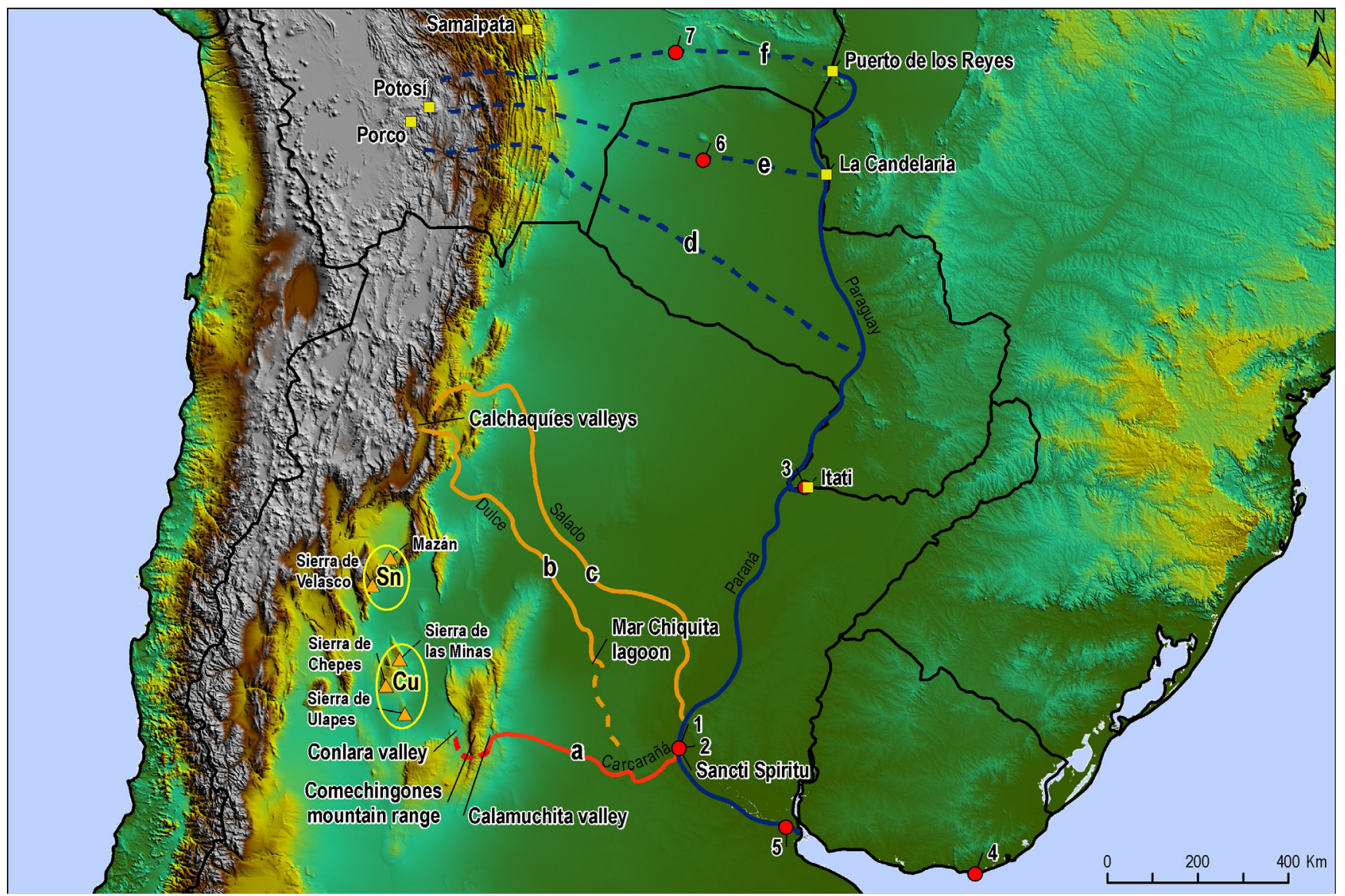

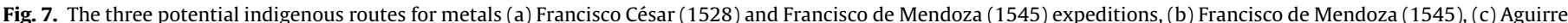

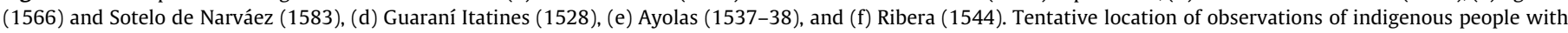

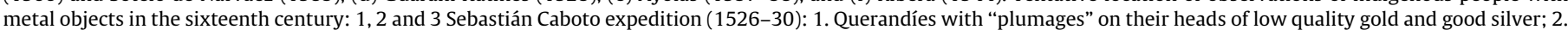

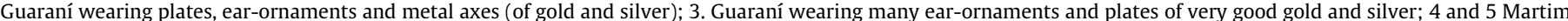

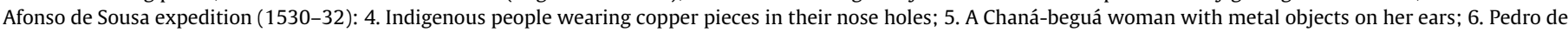

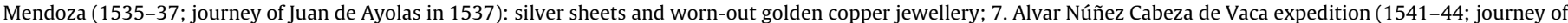

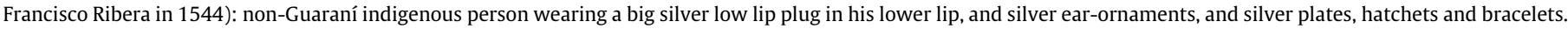

closer areas in the provinces of Córdoba (Cu), Corrientes $(\mathrm{Cu})$, San Luis $(\mathrm{Cu}$ and $\mathrm{Sn})$ and in the Uruguay Republic $(\mathrm{Cu})$, where $\mathrm{Cu}$ or Sn ores were exploited in historical times or are currently exploited (Angelelli, 1984; Araújo, 1900; Godeas et al., 1999), to date no clear archaeological or ethnohistorical evidence has demonstrated the development of local pre-Hispanic metallurgy. This is a prerequisite to explaining the production sequence of smelting, casting, hammering, drilling, and polishing of the metal objects that reached the Paraná Delta.

According to early chronicles, one of the main indigenous routes through which metal ornaments and other products reached the Chaná-timbú people in the Paraná River was following the course of one of its tributaries, the Carcarañá River. This route possibly followed the Tercero River and the Calamuchita valley and then crossed the Mountain Ranges of the Comechingones in Córdoba (Fig. 7). Francisco del Puerto, one of the interpreters that arrived in the region with Solís expedition in 1515 and was held captive by indigenous people for years, later said to Caboto (in Medina, 1908:158, 159) that through the Carcarañá River that descends from the mountain ranges one has access to gold and silver goods. The presence of metals in the "inlands" (approximately 500$900 \mathrm{~km}$ away) was also mentioned by Querandí and Chaná-timbú groups that went to Sancti Spiritus fort (1527-1529), founded by Caboto not coincidentally at the mouth of the Carcarañá River. Later, Captain Francisco César and his fellow travellers also confirmed this version when they returned from their inland journey in search of the Sierra de la Plata [Mountain Range of Silver], where they reached the Conlara valley (Serrano, 1945: 40).

Years later, in 1536, the Timbú and Carcaraes people in the Corpus Christi port (1536-1539?), north of Sancti Spiritus fort, also informed the Spaniards (Díaz de Guzmán [1612], 2010:55) that in a south-westward direction, and through the land of the Comechingones in Cordoba, "nations very rich in silver and gold" could be reached. This indigenous knowledge about the way to the metals (mentioned by chroniclers) opens up the possibility not only that there were pre-Hispanic routes, but also that it was the indigenous people of the Paraná River themselves who went to look for metals and other products. Along the same route, but towards the east, Francisco de Mendoza was led by indigenous guides from Calamuchita River along Tercero River (Córdoba) to the ruins of Sancti Spiritus fort in 1545 (Berberián, 1987:11). This shows that an inverse situation was also possible: it may have been the indigenous groups from Córdoba who reached the Paraná River. In addition to these possible two-way movements, the Querandies foragers of the Pampas region also used this route. Thus, they could have acted as intermediaries between the indigenous groups from Córdoba and the Paraná River.

(2) Based on the archaeological record from Santiago del Estero plains, Taboada (2014) has proposed the existence of non-occasional contacts with Goya-Malabrigo populations from the Middle 
Paraná River and the Paraná Delta. Goya-Malabrigo is the archaeological expression of the Chaná-timbú people described in early historical documents (see Politis and Bonomo, 2012). These contacts could have involved the circulation of metals because the archaeological record from Santiago del Estero Province, especially in the Middle Salado River, includes $\mathrm{Cu}$ beads and other preHispanic objects made of copper and tin bronze (and others of silver and gold). Their formal design resembles that of the late metallic objects belonging to the archaeological record of the NWA valleys (e.g., sheets, axes, bells, and gauntlets) as well as Inca artefacts (e.g., topus -pins-, tumis and toki -axes-, T-shaped axes and star-shaped maces) (Pedersen, 1952; Angiorama and Taboada, 2008). In this area of Santiago del Estero there are neither metalliferous deposits nor a local metallurgic tradition, indicating that the pre-Hispanic metal objects were brought from the southern Andes region (Lorandi, 2015), most of them probably during the times of the Inca Empire called Tawantinsuyu (Angiorama and Taboada, 2008). They are mainly ornaments often found in funerary contexts, which have been interpreted as prestige goods (Taboada, 2014), many of them as symbols of power and social status, which were possibly special gifts from the Incas to local Santiago del Estero populations as part of alliances or in exchange for some services.

The second route is along the Salado and Dulce Rivers (Fig. 7). The Salado River runs in a NW-SE direction, like the Dulce River, and flows into the Paraná River. Its headwaters are located in the Calchaquí valleys in NWA, where there were mines and had a developed pre-Hispanic metallurgy, as acknowledged in early South American archaeometallurgic studies (Amborsetti, 1904). The Salado River was used by the Spaniards as a terrestrial route, sometimes by sections, to go to NWA and Peru through Santiago del Estero Province during the sixteenth century (Francisco de Mendoza 1545 and Aguirre 1566 in Serrano, 1945; Sotelo de Narváez 1583 in Berberián, 1987:238-240). The journey along the Dulce River to Mar Chiquita Lagoon in Córdoba Province was made by Francisco de Mendoza (1545), whereby it is presumed that the indigenous guide was trying to take him to the Paraná River (Serrano, 1945:41). The Juríes populations, who lived by the Dulce River in Santiago del Estero during the sixteenth century, knew the main chief of the Timbú called Corundá (Serrano, 1945:274). Therefore, they may have been to the Paraná River themselves.

(3) In the case of the Guaraní, there is a strong relationship and spatial overlap between the archaeological record (consisting mainly of distinctive pottery, lip plugs, stone axes, and urn burials) and the distribution of the Guaraní people at the moment of the European conquest (see Bonomo et al., 2015). The archaeological evidence from the Upper Paraná River includes copper/bronze pendants along with human burials inside Guaraní urns (Max Schmidt Collection, Museo Etnográfico Andrés Barbero, Asunción, Paraguay). According to early written sources, these objects could have been brought to the Paraná River from the Southern Andes, across Chaco region and along the Paraguay River (Fig. 7). Indigenous sources informed Caboto in Sancti Spiritus (in Medina, 1908:159) that in the Paraguay River he would find riches (it is interesting to note that the same information was provided to the Portuguese Lopes de Sousa [1531], 1861:32- far away from there, in Rio de Janeiro, Brazil). This may have been another of the main preHispanic routes to obtain silver, gold, and copper, in this case used by Guaraní groups from the Paraná River. In the well-known letter by Luis Ramírez (1528), a member of Caboto expedition, it is made clear that the Paraguay-Paraná fluvial corridor was one of the itineraries to gain access to metals and that they knew their Andean origin. During an encounter with Guaraní people in Itatí area (in the north of current Corrientes Province, Argentina), Ramírez (1528 in Madero, 1902:404) mentions that "we saw these Indians bringing many ear-ornaments and plates of good gold and silver".
Francisco del Puerto was told that these metal objects were exchanged for beads and canoes with other Guaraní groups settled sixty or seventy leagues upstream Paraguay River. In turn, they obtained plates, ear-ornaments and axes, after a six-day journey on foot to the west to the known Sierra de la Plata, mountain range where the Guaraní continuously travelled, sometimes in large numbers, to trade with its inhabitants (Ramírez, 1528 in Madero, 1902: 393, 394, 400, 405). This mountain range where the metals came from was also called Sierra del Rey Blanco. It was very well known in a wide region within the southern La Plata basin and by different groups, such as the Querandies from the Pampas region and the Guaraní from Corrientes Province, Paraguay, and Santa Catarina State in southern Brazil. The bright metals had a great value and magical power for the Guaraní and were associated with the Andean Candiré, as they called "the country of the metals and of good" (Susnik, 1993). During the specific trips that the Guaraní took in search of metal, they had not only to cross the Chaco and the marshes and lagoons of the Chiquitanía, but also to pass through the lands of numerous ethnic groups with whom they would have interacted. Even the search for metals without intermediaries and the direct theft from mining settlements were powerful incentives for the repeated population movements towards the west made by the Paraguay river Guaraní (named Itatines; Combès, 2015).

As Combès (2008) accurately points out, it was in search of metal sources and following pre-existing indigenous routes that successive Spanish expeditions departed between 1530 and 1548 for the lands to the west of the Paraguay River. Juan de Ayolas (1537-1538), Domingo de Irala (1542-1543) and Francisco Ribera (1544) were the most important expeditions because of the ethnohistorical data they provide. Ayolas apparently reached the Chanés and Payzunos indigenous of the Arawak ethnolinguistic group. He saw large fenced villages that had "a lot of silver, gold and sheep from Peru" (Fernández de Oviedo y Valdés [1546-47], 1852:200; see also Villalta in Schmidl [1567], 2009). There he obtained a significant load from the Sierra de la Plata. On his trip to the Upper Paraguay River, Irala mentions numerous populations in the region (Payzunos, Chanés, Carcaraes, Chimenos, Candires, Gorgotoquis, Mbayá, just to name a few) that possessed gold and silver objects, and who knew where they came from and how to get them (see Combès, 2008:54). Francisco Ribera reached the vicinity of Tapuaguazu hill (at the west of Puerto de los Reyes) in 1544 where nonGuaraní groups (the Tarapecocies) had silver ornaments and tools (Núñez Cabeza de Vaca [1541-1544], 2014:175; Hernández [1545] in Schmidl [1567], 2009:212-213). He was informed there about the interethnic trade circuit that metal objects followed: they got the gold and silver from "the Payzunos, who are three days away from their land, they give them in trade for bows and arrows and slaves that they take from other nations, and the Payzunos obtain them from the Chanés and Chimenos and Carcaraes and Candires, who are other Indian people, who have lots of them..." (Núñez Cabeza de Vaca [1541-1544], 2014:177). Among these inland ethnic groups, Combès, (2008:58) highlights the Candires (the Incas from the Samaipata fortress) and the Chimenos and Carcaraes (Aymara people from the Charcas area in the Bolivian altiplano) whom Paraguayan indigenous people described as the "true lords of metal", since they were the ones who "take out" the metal, that is, who owned the mines of Charcas, including Porco and Potosí, among others. The Payzunos and Chanés, in turn, were the main intermediaries.

In addition to the intensive exchange and traffic of silver, gold, and copper goods on a pan-regional scale, metals circulated as gifts and were obtained at war. For example, the Inca leader of Samaipata sent through the Chanés travellers 'metal gifts' to the indigenous people from Pantanal in the Upper Paraguay River (Susnik, 1993:8). About four kilometres west of this river, 
approximately at the same level as Puerto de los Reyes, Inca pottery and a copper plate were recovered (Dames and Moore, Inc., 2001), also showing archaeological evidence of the existence of these circuits. Another mechanism for obtaining metals such as "plates and silver crowns" was robbery "in the wars with the Indians of Peru" (Anonymous 1537 in Medina, 1908:181-182).

The metals that circulated between the Andes and the Lowlands are in both macro regions linked to a symbolic religious sphere as well as prestige or social rank differences between individuals (González, 2002; Lechtman, 1988; Olsen Bruhns, 1994; Susnik, 1993). Metal objects were part of prestige technologies (sensu Hayden, 1998) oriented towards social strategies that made it possible to communicate power and status differences among the individuals that possessed, used, and displayed them (Goldstein, 2000). The archaeological and ethnohistorical records of the southern La Plata basin show that metal objects can be material correlates of social differences between individuals (Bonomo et al., 2011). The archaeological record of the Paraná Delta shows that only a few individuals were buried with copper and bronze beads and pendants. The differential treatment performed on these individuals when they died could be a sign of asymmetrical social relationships in which only some members of the society had preferential access to certain exchange goods. In this sense, in the chronicles from the Paraná River these pieces appear associated with indigenous leaders with some ability to command over the other members of their community, called by the Spaniards "mayorales" (or also "principal" chiefs). Caboto's statement in 1530 shows the display of these metal ornaments by one of these leaders: “....a chief of the Chandules [Guaraní] nation... who showed him a 'coif' with some sort of plate in gold or copper and some sort of low quality silver, which he took from his head to give it to him..." (in Medina, 1908:158). These imported objects, which were not for daily access or use, functioned as visible symbols of prestige (Goldstein, 2000; Zvelevil, 2006) and served to highlight differences within the groups, giving greater status to the local characters that possessed them and possibly controlled their exchange.

\section{Conclusions}

The obtained results allow us to reach the following conclusions:

1. The metal objects recovered in the Paraná Delta were mainly manufactured in pure $\mathrm{Cu}$ and, in one case, with a bronze alloy. The analysed objects could have been made by melting small ingots, prills or pieces of scrap metal, and then casting in open moulds. The thin thickness of some pieces was achieved through mechanical work by hammering. Regarding the production sequence in the Delta collections, we have only finished ornaments, although unfinished sheets may have reached the area.

2. The populations of the Paraná Delta did not have either direct links to the original sources or control over the production process of metals. Pendants and beads made of bright metals came to the Lower Paraná as a result of exchange circuits involving transport across huge distances from the metallurgical production centres in the Meridional Andean Area. With the basic metallurgic studies carried out here, we cannot yet determine the specific geological origin of copper or whether it was obtained as native copper or in some copper minerals from the Andes mines. These circuits were part of a continuous flow of information, people, barter objects, gifts, and spoils of war/ theft between the East and the West. These Andean goods were taken along existing indigenous routes from pre-Hispanic times until arrival at the Paraná River. Hypothetically, metals may have come through three indigenous routes: two of them, the Carcarañá River across the Mountain Ranges of Cordoba and the Salado-Dulce Rivers through the plains of Santiago del Estero, used by Chaná-timbú groups; and a third one, the Paraná-Paraguay River route through Chaco, followed by Guaraní populations. Obviously, the evidence is not conclusive, since it is not possible to confirm whether the three potential routes mentioned, or at least one of them, were indeed the path followed by the metallic objects studied from their source of origin to their context of discovery.

3. Metal objects were possibly used to mark social rank differences within the groups. The ethnohistorical record shows that they were symbols of prestige displayed by indigenous leaders. The archaeological record shows the final destination of these sumptuous goods when they were frequently placed in burials along with the bodies of few individuals. Imported objects could have generated differences within the groups, giving greater status to local individuals that possessed them and symbolizing their special privileges. By controlling the exchange of products from distant geographical areas, these individuals had access to sophisticated goods (metal manufactures), which could be used to strengthen their social position, prestige and leadership.

\section{Acknowledgments}

We would like to thank three anonymous reviewers for their useful comments which improved an earlier version of the manuscript, Carlos Ceruti, Andrés Gascué, Josefina Spina, Juan Carlos Castro and Gabriel Cocco for the information provided; Dr. Gustavo Vigna, Silvia A. Dominguez and all the staff from the Grupo de Metalografía del Departamento de Materiales (Centro Atómico Constituyentes, Comisión Nacional de Energía Atómica), who collaborated with this research; Guillermo Álvarez (LEMIT; CIC) with whom we initially started the study of the metal pieces presented in this paper; Yolanda Porto (Laboratorio de Arqueoloxía da Paisaxe de Santiago de Compostela, España) for the Cu oxides and carbonates identification, and the mechanical cleaning of the pieces under stereomicroscope to improve their conservation conditions. These studies are part of the research projects "Las estructuras monticulares del Delta Superior del Paraná” (ANPCyT; PICT 0665) and "Farming, Mound Building, and Social Complexity in the Upper Delta of the Paraná River" (National Geographic Society, grant \# 9328-13).

\section{References}

Amborsetti, J.B., 1904. El bronce en la región calchaquí. Anales del Museo Nacional de Buenos Aires 11, 163-312.

Areces, N., de Bernardi, C., Tarrago, G., 1989-90. Blancos e indios en el corredor fluvial paranaense. Anuario 14, 341-362.

Angelelli, V., 1984. Yacimientos Metalíferos De La República Argentina, I, Comisión De Investigaciones Científicas De La Provincia De Buenos Aires. Facultad de Ciencias Naturales y Museo, UNLP, La Plata.

Angiorama, C.I., 2001. De metales, minerales y yacimientos. Contribución al estudio de la metalurgia prehispánica en el extremo noroccidental de Argentina. Estudios Atacameños 21, 63-87.

Angiorama, C.I., Taboada, C., 2008. Metales andinos en la llanura santiagueña (Argentina). Revista Andina 47, 117-150.

Araújo, O., 1900. Diccionario Geográfico Del Uruguay. Editorial Artística Dornaleche y Reyes, Montevideo.

Berberián, E.E., 1987. Crónicas Del Tucumán. Siglo XVI. Comechingonia. Revista de Antropología e Historia, Córdoba.

Bernal, V., 2008. Procesos de diferenciación biológica entre poblaciones humanas del Holoceno tardío de Patagonia. Una aproximación desde la variación métrica dental (Unpublished PhD dissertation). Facultad de Ciencias Naturales y Museo, Universidad Nacional de La Plata, La Plata.

Bonomo, M., Capdepont, I., Matarrese, A., 2009. Alcances en el estudio de colecciones. Los materiales arqueológicos del Delta del río Paraná depositados en el Museo de La Plata (Argentina). Revista de Arqueología Sudamericana 5, 68-101. 
Bonomo, M., Politis, G.G., Gianotti, C., 2011. Montículos, jerarquía social y horticultura en las sociedades indígenas del Delta del río Paraná (Argentina). Latin Am. Antiquity 22 (3), 297-333.

Bonomo, M., Angrizani, R., Apolinaire, E., Noelli, F.S., 2015. A model for the Guaraní expansion in the La Plata Basin and littoral zone of southern Brazil. Q. Int. 356, 54-73.

Campos, P.M., 2009. Interpretación de los fragmentos de refractarios del poblado prehispánico de Rincón Chico, Catamarca. In: Oliva, F., de Grandis, N., Rodríguez, J. (Eds.), Arqueología Argentina en los inicios de un nuevo siglo, vol. II. Universidad Nacional de Rosario, Rosario, pp. 15-24.

Ceruti, C., 1993. Arqueología. In: Renna, A.D. (Ed.), Nueva Enciclopedia de la Provincia de Santa Fe, vol. IV. Ediciones Sudamérica, Santa Fe, pp. 557-580.

Combès, I., 2008. Planchas, brazaletes y hachuelas: las rutas prehispánicas del metal andino desde el Guapay hasta el Pantanal. Revista Andina 47, 53-82.

Combès, I., 2015. De La Una Y Otra Banda Del Río Paraguay. Historia Y Etnografía De Los Itatines (Siglos XVI-XVIII). Instituto de Misionología, Cochabamba.

Dames and Moore, Inc., 2001. Al Este De Los Andes, Al Sur Del Amazonas. Descubrimientos Arqueológicos en los Bosques Secos de los Llanos de Bolivia, Landivar, Santa Cruz de la Sierra.

Debenedetti, S., 1910. Noticia sobre un cementerio indígena de Baradero (prov. de Buenos Aires). Revista de la Universidad de Buenos Aires XIII-XIV 70, 435-452.

Díaz de Guzmán, R., [1612], 2010. La Argentina. Claridad, Avellaneda.

Fernández de Oviedo y Valdés, G., [1546-47], 1852. Historia general y natural de las Indias, Islas y Tierra Firme del Mar Océano. Guarania, Asunción del Paraguay.

Fester, G.A., Retamar, J.A., 1955. Examen de piezas provenientes de la antigua ciudad de Santa Fe. Revista de Ingeniería Química 33 (24), 95-105.

Godeas, M., Cardó, R., Carrizo, R., Cruz Zuloeta, G., González (h), R., Korzeniewsky, L. I., López, H., Mallimacci, H., Martínez, L., Ramallo, E., Valladares, H., Zubia, M., 1999. Inventario de yacimientos y manifestaciones de minerales metalíferos e industriales de la República Argentina. In: Zappettini, E.O. (Ed.), Recursos Minerales De La República Argentina, Anales, Instituto de Geología y Recursos Minerales, Vol. 35. SEGEMAR, Buenos Aires, pp. 1979-2173.

Goldstein, P.S., 2000. Exotic goods and everyday chiefs: long-distance exchange and indigenous sociopolitical development in the south central Andes. Latin Am. Antiquity 11 (4), 335-361.

Gómez Otero, J., 2003. Movilidad y contactos en la costa centro-norte de Patagonia argentina en tiempos pre y posthispánicos. In: Mandrini, R., Paz, C.D. (Eds.), Las Fronteras Hispanocriollas Del Mundo Indígena Latinoamericano En Los Siglos XVIII-XIX. Un Estudio Comparativo. UNCo, UNCPBA, UNS, Neuquén, pp. 287 312.

González, A.R., 1992. Las Placas Metálicas De Los Andes Del Sur. Kava, Berlín.

González, L.R., 1992. Fundir es morir un poco. Restos de actividades metalúrgicas en el valle de Santa María. Pcia. de Catamarca. Palimpsesto 2, 51-70.

González, L.R., 2002. A sangre y fuego. Nuevos datos sobre la metalurgia Aguada. Estudios Atacameños 24, 21-37.

González, L.R., Gluzman, G.A., 2007. Innovación y continuidad en la metalurgia del Noroeste Argentino. El caso del bronce. Mundo de Antes 5, 187-210.

González, L.R., Gluzman, G.A., Estevez, J.M., 2011. Bronces en tránsito. Metales del Noroeste Argentino e interacción surandina. In: Guiance, A. (Ed.), Movilidad Y Migraciones. IMHICIHU-Conicet, Buenos Aires, pp. 267-278.

Hayden, B., 1998. Practical and prestige technologies: the evolution of material systems. J. Archaeol. Method Theory 5 (1), 1-55.

Hilbert, K., 1986. Kupferschmuck vom Río de la Plata. Marburger Studien zur Vorund Frühgeschichte 7, 81-90 (Gedenkschrift für Gero von Merhart).

Keating, V., Maranhão, R., 2011. Diário De Navegação. Pero Lopes E a Expedição De Martim Afonso De Sousa (1530-1532). Terceiro Nome, São Paulo.

Lechtman, H., 1988. Traditions and styles in central andean metalworking. In: Maddin, R. (Ed.), The Beginning of the Use of Metals and Alloys. MIT Press, Cambridge, pp. 344-378.

Lopes De Sousa, P., [1531], 1861. Diario de Navegação de Pero Lopes de Sousa (de 1530 a 1532). Revista Trimensal do Instituto Historio Geographico e Etnographico do Brasil 24, 9-74

Loponte, D., Acosta, A., Capparelli, I., Pérez, M., 2011. La arqueología guaraní en el extremo meridional de la cuenca del Plata. In: Acosta, A., Loponte, D. (Eds.), Arqueología Tupiguaraní. Instituto Nacional de Antropología y Pensamiento Latinoamericano, Buenos Aires, pp. 111-157.

Lorandi, A.M., 2015. Tukuma - Tukuymanta. Los Pueblos Del Búho. Santiago Del Estero Antes De La Conquista. Subsecretaría de Cultura, Provincia de Santiago del Estero, Santiago del Estero.
Lothrop, S.K., 1932. Indians of the Paraná Delta, Argentina. Ann. New York Acad. Sci. $32,77-232$.

Madero, E., 1902. Historia Del Puerto De Buenos Aires. La Nación, Buenos Aires.

Mazza, B., 2015. Colecciones antiguas, datos nuevos: Primeros resultados del análisis de las colecciones bioarqueológicas del Humedal del Paraná Inferior. Revista del Museo de Antropología 8 (1), 133-146.

Medina, J.T., 1908. El Veneciano Sebastián Caboto Al Servicio De España. Universitaria, Santiago de Chile.

Ministerio de Educación y Cultura (MEC), 1989. Misión De Rescate Arqueológico Salto Grande, vol. 2. MEC, Montevideo.

Núñez Cabeza de Vaca, A., [1541-1544], 2014. Naufragios y Comentarios. Claridad, Buenos Aires.

Olsen Bruhns, K., 1994. Ancient South America. Cambridge University Press, Cambridge.

Ottalagano, F.V., Darigo, M., Pereyra, B., Brancatelli, C., Iannelli, L., 2015. Investigaciones arqueológicas en el sitio La Palmera 2 (cuenca del Paraná medio, provincia de Entre Ríos, Nordeste de Argentina). Revista de Antropología del Museo de Entre Ríos 1 (1), 55-65.

Palacios, T.A., 2011. Metalurgia prehispánica de Sudamérica. Asociación Argentina de Materiales 8 (2), 15-28.

Pedersen, A., 1952. Objetos de bronce de la zona del río Salado (región Chacosantiagueña). In: Proceedings of the Thirtieth International Congress of Americanists. The Royal Anthropological Institute, London, pp. 92-100.

Pifferetti, A., 2001. Algunos casos de corrosión por terrenos en aleaciones de cobre de origen arqueológico. In: Proceedings of the Jornadas SAM-CONAMET. Sociedad Argentina de Materiales, Posadas, pp. 787-794.

Pifferetti, A., 2002. La Tecnología Metalúrgica Del Períodos Formativo Del Noroeste Argentino. Memoirs of the Round Table Tecnologías Metalúrgicas En América Prehispánica. Universidad Autónoma de México, México D.F., pp. 117-128.

Politis, G., Bonomo, M., 2012. La entidad arqueológica Goya-Malabrigo (Ríos Paraná y Uruguay) y su filiación Arawak. Boletín de la Sociedade de Arqueologia Brasileira (SAB) 25 (1), 10-46.

Politis, G., Bonomo, M., Moreira, G., 2015. Análisis de la colección del Túmulo II de Brazo Largo (Islas del Ibicuy, provincia de Entre Ríos). Paper presented at the VI Encuentro de Discusión de Arqueología del Nordeste Argentino. Gualeguaychú.

Prümers, H., 2007. ¿ "Charlatanocracia» en Mojos? investigaciones arqueológicas en la Loma Salvatierra, Beni, Bolivia. Boletín de Arqueología PUCP 11, 103-116.

Schmidl, U., 2009. [1567]. Viaje al Río de La Plata. Translated by Samuel Lafone Quevedo. Claridad, Buenos Aires.

Serrano, A., 1934. Noticia sobre un paradero indígena de la margen izquierda del arroyo Las Conchas (Departamento Paraná, Entre Ríos). In: Proceedings of the XXV International Congress of Americanists. Coni, La Plata, pp. 165-172.

Serrano, A., 1945. Los Comechingones. Universidad Nacional de Córdoba, Córdoba.

Serrano, A., 1950. Los Primitivos Habitantes De Entre Ríos. Biblioteca Entrerriana "General Perón". Ministerio de Educación, Provincia de Entre Ríos, Paraná.

Steward, J., 1944-49.. South American Cultures: An Interpretative Summary. In: Steward, J. (Ed.), Handbook of South American Indians, vol. 5. Bureau of American Ethnology, Bulletin 143, U.S. Government Printing Office, Washington D.C, pp. 669-818.

Susnik, B., 1993. Una Visión Socio-Antropológica Del Paraguay. XVI-1/2 XVII. Museo Etnográfico "Andrés Barbero". Asunción.

Taboada, C., 2014. Sequía Vieja y los bañados de Añatuya en Santiago del Estero. Nodo de desarrollo local e interacción macrorregional. Comechingonia. Revista de Arqueología 18, 93-116.

Tapia, A.H., Landa, C., De Rosa, H., Montanari, E., 2009. Artefactos metálicos de las inhumaciones del "Cementerio Indígena" de Baradero. Arqueometría Latinoamericana. Proceedings of the 2do Congreso Argentino, 1ro Latinoamericano, vol. 1. Comisión Nacional de Energía Atómica, Buenos Aires, pp. 263-269.

Torres, L.M., 1911. Los Primitivos Habitantes Del Delta Del Paraná. Universidad Nacional de La Plata, Biblioteca Centenaria 4, Buenos Aires.

Villegas Basavilbaso, F., 1937. Un paradero indígena en la margen izquierda del río Matanzas. Relaciones de la Sociedad Argentina de Antropología 1 (1), 59-63.

Zvelevil, M., 2006. Mobility, contact, and exchange in the Baltic Sea basin 60002000 BC. J. Anthropol. Archaeol. 25, 178-192. 